\title{
Phytocompounds of Bistorta macrophylla (D. Don) Sojak. as bioavailability enhancers of fluconazole and amphotericin B to better manage Candida species infections
}

\author{
Rajan Rolta \\ SHOOLINI UNIVERSITY \\ Shivani Shukla \\ Shoolini University \\ Anjali Kashyap \\ Shoolini University \\ Vikas Kumar \\ Shoolini University \\ Anuradha Sourirajan \\ Shoolini University \\ Kamal Dev ( $\sim$ kamaldevbhardwaj1969@gmail.com ) \\ Shoolini University
}

\section{Research Article}

Keywords: Bistorta macrophylla (D. Don) Sojak, Antifungal activity, Candida albicans, Synergistic activity

Posted Date: January 3rd, 2022

DOI: https://doi.org/10.21203/rs.3.rs-1216369/v1

License: (c) (i) This work is licensed under a Creative Commons Attribution 4.0 International License. Read Full License 


\section{Abstract}

Bistorta macrophylla (D. Don) Sojak. is a medicinal plant of high altitude and so far, not been scientifically explored? Since prehistoric times, B. macrophylla has been used to cure stomach pain, pyretic fever, flu, lungs infections, diarrhea, vomiting. The present research was aimed to examine the phytochemicals, antifungal, and synergistic potential of methanolic extracts of $B$. macrophylla. Methanolic extract of $B$. macrophylla was found to have high phenolic $\left(191.18 \pm 29.18 \mathrm{mg} \mathrm{g}^{-1} \mathrm{GAE}\right)$ and flavonoid $\left(26.71 \pm 3.21 \mathrm{mg} \mathrm{g}^{-1} \mathrm{RE}\right)$ content. Methanolic extract also demonstrate strong antifungal action with diameter of zone of inhibition of $17.5 \pm 0.5$ $\mathrm{mm}$ (fungicidal) against both the strains of $C$. albicans (MTCC277 and ATCC90028). The minimal inhibitory concentration (MIC) of methanolic extract was found to be $62.5 \mu \mathrm{g} \mathrm{ml}^{-1}$ against $C$. albicans (MTCC277 and ATCC90028). In addition, the combination of methanolic extract of $B$. macrophylla with antifungal antibiotics (fluconazole and amphotericin B) showed synergistic interaction with MIC reduction from 4-128 folds against both candida strains. GC-MS analysis of methanolic extract revealed the presence of 15 major phytocompounds with area more than $1 \%$. Molecular docking showed that sucrose and 9,9-Dimethoxybicyclo [ 3.3.1] nona-2,4-dione has highest binding energy of -6.3 and $-5.1 \mathrm{KJ} / \mathrm{mol}$ against Cytochrome $\mathrm{P} 45014$ alphasterol Demethylase (PDB ID: 1EA1) protein respectively. Combination of methanolic extract of $B$. macrophylla with antifungal antibiotics (fluconazole, amphotericin B) can be used to treat drug-resistant candida.

\section{Introduction}

Since prehistoric time, medicinal plants and herbs have been discovered and used in folk medicine (Stojanoski 1999). Now phytocompounds are at the forefront of drug discovery. According to World Health Organization (WHO), "Any plant whose one or more part, contain substance that can be used for therapeutic purpose or which is a precursor for synthesis of useful drugs" is classified as medicinal plant. WHO has estimated that about $80 \%$ of the World population rely almost exclusively on traditional medicine for their primary healthcare needs (Farnsworth 1988). Medicinal plants are the "backbone" of traditional medicine system, and most of the people in the less developed countries utilized these traditional medicinal plants on a regular basis (DavidsonHunt 2000) for their well-being. Plants produce or secrete an array of chemical compounds and use them for various biological functions including defense against insects, fungi and bacteria. Scientists are now exploring these phytocompounds as novel therapeutics approach to solve the emerging issues of multi-drug resistance (Rolta et al. 2020b; Rolta et al. 2021; Salaria et al. 2021). Antimicrobial resistance is a major threat to animal and human health development, affecting our ability to treat a range of infections. Treatments for a growing number of infections have become less effective in many parts of the world due to emergence of drug resistance (WHO 2016). Among many other diseases, candidiasis caused by Candida albicans is one of the major concerns (López-Martínez 2010). Fluconazole and amphotericin B are the most commonly and widely used antibiotics to treat Candidiasis. Some strains of Candia have developed resistance (antifungal resistance) to these antibiotics and are difficult to treat (Helmerhorst et al. 1999). The rise of antifungal resistance is very high and discovery of new antibiotics is very slow. Centres for disease control and prevention (CDC) has reported that some strains of Candida are highly resistant to even first line and second line of antifungal medications, such as fluconazole and the echinocandins (anidulafungin, caspofungin, and micafungin). Candida auris has been reported to be resistant to fluconazole and amphotericin B and now it has become a serious health concern (Satoh et al. 2009; Lockhart et al. 2016). The individual with drug resistant infection has to consume higher dosage of antibiotics, which in turn leads to emergence of drug resistance and also 
responsible for many side effects and ultimately life expectancy (Gould et al. 2013). The mechanisms of antibiotic resistance in mainly due to mutation in gene encoading the target site of FQs (DNA gyrase and topoisomerase IV), over expression of efflux pumps and protection of the FQ target site by a protein designated Qnr (Munita and Arias 2016). The combination therapy of two or more antibiotics (synergism) has been in practice for some, but this has also resulted in selection pressure on pathogens and drug toxicity (Dudhatra et al. 2012).

Therefore, the current need is to search for molecules that are not antibiotics itself, but enhance the potency /availability of the antibiotics. Such molecules should be non-toxic and enhance the bioavailability of antibiotics in combination and act synergistically. Potent bio-enhancers could potentially lower the dosage of antibiotics and therefore reduced toxicity to the host. Phytochemicals of medicinal plants have huge potential to be developed as bio-enhancer of antibiotics and feed the drug discovery pipeline to develop new therapies to manage candidiasis. India has huge diversity of medicinal plants and rich system of traditional medicines and ethno pharmacology. Especially, Himalayan region houses 1748 species of unique medicinal plants with various traditional and modern therapeutic uses (Samant et al. 1998), including 675 species of wild edible plants (Samant and Dhar 1997) and 118 species of medicinal plants yielding essential oils. High altitude of Himalayas is a unique habitat that resulted in the accumulation of unique phytoconstituents in medicinal plants and warrants their exploitation in a holistic manner to counter the problem of multidrug resistance and for the well-being of people. The Indian sub-continent is suitable for cultivation of large number of medicinal and aromatic plants, which can be used as raw materials for pharmaceuticals, perfumery, cosmetics, flavors and food. The Chanshal valley of Himachal Pradesh is regarded as hub of medicinal plants and trees. It contains several species of medicinal plants and trees e.g. Rheum emodi, Juniperus communis, Bistorta macrophylla, Jurinea macrocephala, Picrorhiza kurroa, Pleurospermum bruninis and Betula utilis etc. and people of Dodra Quar and Rohru region utilize these medicinal plants or trees for the cure and preventions of different diseases (Jaundice, wound healing, fever, cough, respiratory problems, boils, nerve disorder, dysentery ulcers etc.) since ancient time.

B. macrophylla is one of the important and unexplored medicinal plant species of alpine region of Himalayas and is commonly known as Kukhri, Chhotaninayin, Kande-re-ninai in Hindi and Snakeweed in English. $B$. macrophylla belongs to family polygonaceae. $B$. macrophylla is a stout perennial herb and arise from a woody root stock (rhizome), reticulate. It is native to mountain regions of West-China, Pakistan, Bhutan, North India (Himachal Pradesh, Uttarakhand), West India (Western Ghats) and Nepal (Chauhan 1999). In India, it is distributed at altitudes ranging from 3300 to 3800 meters height in the temperate and subtropical regions of Himalayas (Chauhan 1999). Rhizomes of B. macrophylla are widely used in Ayurvedic and traditional medicine as antidiarrheal, antidysenteric, alleviates stomach pain, anti-inflammatory, and anti-pyretic (Gaur 1999). Traditionally, B. macrophylla is used to cure the stomach problems and paste of $B$. macrophylla rhizome is given to children and infants for stomach problems. Older patients chew the roots for the same problem (Chauhan 1999). Paste and powder of B. macrophylla roots was taken orally to cure fever, ulcer and toothache. Paste of $B$. macrophylla roots by prepared by rubbing roots on hard surface of stone with few drops water. It is also used to cure tuberculosis, inflammation, pyretic fever, flu, lungs disorders, diarrhea, vomiting, arthritis, gout, kidney stones or hyperacidity and hypertension (Wangchuk et al. 2016). B. macrophylla is known for its traditional medicinal values, but not explored scientifically, except one report by Chandra et al. (2016). Therefore, the current study was designed to study the potential of methanolic extract of rhizome of unexplored 
B. macrophylla as bioavailability enhancer of fluconazole and amphotericin B against to manage candidiasis and identify the major phytocompounds by GC-MS analysis.

\section{Materials And Methods}

\subsection{Collection of B. macrophylla samples and preparation of rhizome extract using Soxhlet extraction method}

The rhizomes of B. macrophylla were collected from the Chanshal valley of District Shimla (latitude-31.196925 ${ }^{\circ} \mathrm{N}$ and longitude: $77.988675^{\circ} \mathrm{E}$ ), Himachal Pradesh (India) in the month of August, 2017 (Figure 1). The collected plant samples of Bistorta macrophylla (D. Don) Soják were identified from Dr Y. S. Parmar University of Horticulture and Forestry, Nauni, Himachal Pradesh (India) with reference no. UHF-13583 and plant name has been verified at http://www.theplantlist.org.

The rhizome of $B$. macrophylla was thoroughly washed with running tap water to remove the soil particles and surface sterilized using $70 \%$ ethanol for 2 minutes, followed by washing with sterilized distilled water. The rhizomes were cut into small pieces and dried in hot air oven at $40{ }^{\circ} \mathrm{C}$ (until no further reduction in weight for 6 h) and then ground to fine powder with the help of electric grinder.

About 50 grams of dried powder of rhizome of $B$. macrophylla was subjected to methanol (500 ml) extraction using hot continuous method in a Soxhlet apparatus. The extract was filtered through Whatmann filter paper no. 1 and the collected filtrate was dried at $40^{\circ} \mathrm{C}$. The dried methanolic extract was stored at $4{ }^{\circ} \mathrm{C}$ in air tight bottles until further use.

\subsection{Qualitative analysis of phytochemicals present in methanolic extract of $B$. macrophylla}

The rhizome extract of $B$. macrophylla was tested for the presence of major phytocompounds such as phenolics, flavonoids, tannins, saponins, alkaloids, glycosides, phytosteroids and carbohydrate by protocols described earlier (Khandelwal 2008). For the detection of alkaloids and glycosides, $50 \mathrm{mg}$ of methanolic extract was dissolved in $5 \mathrm{ml}$ of diluted $\mathrm{HCl}(1 \%, \mathrm{w} / \mathrm{w})$ and filtered through Whatman filter no1. The resultant filtrate was used for the detection of alkaloids and glycosides. On the other hand, $50 \mathrm{mg}$ of methanolic extract was dissolved in $5 \mathrm{ml}$ of sterilized water and then filtered. The filtrate was used for the detection of phenolics, tannins, phytosterols, phytosteroids, carbohydrate, flavonoids, proteins and amino acids.

\subsection{Quantitative analysis of phenolic contents and flavonoids in methanolic extract of $B$. macrophylla rhizome}

\subsubsection{Quantification of total phenolic contents}

The total phenolic content of methanolic extract of $B$. macrophylla rhizome was determined by using Folinciocalteau reagent (Singleton 1999) total phenolic content was calculated from the calibration curve of gallic acid (5-100 $\mathrm{g} \mathrm{m} \mathrm{m}^{-1}$ ) and expressed in terms of gallic acid equivalents (GAE) per gram of the extract and calculated using the following equation: 
$\mathrm{C}=\frac{\mathrm{c} \times \mathrm{V}}{\mathrm{m}}$

Where ' $C$ ' is total content of phenolic compounds in mg g-1 plant extract in GAE, ' $c$ ' is the concentration of Gallic acid estimated from the calibration curve ( $\mathrm{mg} \mathrm{ml-1),} \mathrm{'} \mathrm{V}$ ' is the volume of extract in milliliter and " $\mathrm{m}$ " is the weight of crude plant extract in grams.

\subsubsection{Quantification of total flavonoid content}

The total flavonoid content of ethanolic extract of rhizome of $B$. macrophylla was quantified using aluminium chloride (AICl3) method (Zhishen et al. 1999). The flavonoid content was calculated from standard curve of rutin (5- $100 \mathrm{\mu g} \mathrm{ml}^{-1}$ ) and expressed as rutin equivalents (RE) per gram of the extract and was calculated by the following equation:

$\mathrm{C}=\frac{\mathbf{c} \times \mathrm{V}}{\mathrm{m}}$

where ' $C$ ' is total content of flavonoid compounds in mg g-1 plant extract in rutin equivalent; ' $c$ ' is the concentration of rutin calculated from the calibration curve in $\mathrm{mg} \mathrm{ml}^{-1}$, ' $\mathrm{V}$ ' is the volume of extract in $\mathrm{ml}$, and ' $\mathrm{m}$ ' is the weight of crude plant extract in grams.

\subsection{Analysis of antifungal activity in methanolic extract of $B$. macrophylla rhizome}

\subsubsection{Microbial Strains and culture conditions}

Two fungal strains such as Candida albicans (ATCC90028 and MTCC277) were used to test the antifungal activity of methanolic extract of B. macrophylla rhizome. Both the fungal strains were obtained from Yeast Biology Lab, Shoolini University, Solan, Himachal Pradesh, India. The fungal strains were grown in yeast extract, peptone and dextrose (YPD) broth at $30{ }^{\circ} \mathrm{C}$ with shaking at $200 \mathrm{rpm}$. The cell turbidity of the culture was adjusted by comparing with $0.5 \mathrm{McF}$ arland standards (Lahuerta and Pérez-Gracia 2012), which is approximately equivalent to $2 \times 10^{8}$ colony forming units (CFU) $\mathrm{ml}^{-1}$ of the culture for antifungal assay. The culture media used in this study were purchased from Himedia Biosciences, Mumbai (India).

2.4.2 Agar well diffusion and Broth dilution assays for measuring antifungal activity of methanolic extract of $B$. macrophylla rhizome

Antifungal activity was tested by using agar well diffusion method (Perez 1990; Rolta et al. 2018 a, b) About 25 $\mathrm{ml}$ of YPD agar medium was poured in sterile $100 \mathrm{~mm}$ petri-dish and allowed to solidify. Then, fungal culture of optical density of $0.12 \sim 0.15$ at $530 \mathrm{~nm}$ equivalent to $0.5 \mathrm{McF}$ arland standard was uniformly spread on the surface of the YPD agar medium using sterile cotton swabs and plated were allowed to dry under aseptic conditions. The wells were punched with the cork borer $(6 \mathrm{~mm})$ in the agar and $50 \mu \mathrm{g}\left(1 \mu \mathrm{g} \mathrm{m}{ }^{-1}\right)$ rhizome extract was loaded in the wells and allowed to diffuse. Assay plates were incubated of $48 \mathrm{~h}$ at $30{ }^{\circ} \mathrm{C}$ and the zone of inhibition was measured using Hi Antibiotic Zone scale-C (Himedia Biosciences, Mumbai (India). Fluconazole filter disk (10 $\mu \mathrm{g})$ purchased from Himedia Biosciences, Mumbai (India) was used as a positive 
control and dimethyl sulphoxide (DMSO) and methanol alone were used as solvent alone as a control in the antifungal assay. The tests were performed in triplicate and results were recorded as mean \pm SD.

2.4.3 Broth dilution assay to determine the minimum inhibitory concentration (MIC) of methanolic extract of $B$. macrophylla rhizome

The minimum inhibitory concentration (MIC) of the methanolic extract of rhizome of $B$. macrophylla was measured by broth dilution method described under CLSI guidelines using 5-tripheny tetrazolium chloride (CLSI 2012). The methanolic extract was dissolved in DMSO and geometric dilutions ranging from 500-0.025 $\mu \mathrm{g}$ $\mathrm{ml}^{-1}$ were prepared in a 96-well microtiter plate, including one growth control (YPD broth containing DMSO) and a positive control (YPD broth inoculated with fungal culture and containing amphotericin B $(25 \mu \mathrm{g})$ or fluconazole $(25 \mu \mathrm{g})$. Assay plates were incubated for 48 hours at $30^{\circ} \mathrm{C}$. Following incubation, 5 -tripheny tetrazolium chloride $(5 \mu \mathrm{g})$ was added to each well and incubation was continued for another $2 \mathrm{~h}$. Change in colour from purple to pink or colourless was observed and used as a measure to calculate the MIC. The lowest concentration at which colour change appeared was considered as the MIC value as descried previously (Rolta et al. 2018a, Rolta et al. 2020a, b).

2.4.4 Synergistic enhancement of antifungal activity of fluconazole and amphotericin B against fungal strains when combined with methanolic extract of rhizome of $B$. macrophylla using broth dilution method

Synergistic interaction of phytocompounds present in methanolic extracts of $B$. macrophylla and fluconazole or amphotericin B were determined using checkerboard method (van Vuuren et al. 2011; Eumkeb et al. 2012, Dev et al. 2017; Rolta et al. 2018b; Bonapace et al. 2020). Briefly, the different combinations of methanolic extract of $B$. macrophylla and antifungal antibiotics were prepared and broth dilution method was performed to determine the MIC as shown in the schematic diagram (Figure 2). The checkerboard method is often combined with calculation of fractional inhibitory concentration (FIC) index (FICI). The FIC was derived from the lowest concentration of antibiotic and plant extracts combination showing no color change. FIC value for each compound was calculated using the following formula:

$\mathrm{FICl}=\mathrm{FIC}$ (fluconazole or amphotericin B) + FIC (rhizome extract of B. macrophylla)

where, FIC (fluconazole or amphotericin B) = MIC of antibiotic in combination/ MIC of antibiotic alone; FIC (rhizome extract of B. macrophylla) = MIC of rhizome extract of B. macrophylla in combination/ MIC of rhizome extract of $B$. macrophylla alone

The interactions were classified as being synergistic with $\Sigma F I C$ values of $\leq 0.5$, additive $(\geq 0.5-1.0)$, indifferent $(\geq 1.0-\leq 4.0)$ or antagonistic ( $\Sigma F I C>4.0$ ) (Nidhi et al. 2020; Rolta et al. 2020 a,b; Salaria et al. 2021; Mehta et al. 2021)

\subsection{GC-MS of methanolic extract of Bistorta macrophylla rhizome}

To identify the phytocompounds in methanolic extract of Bistorta macrophylla, methanolic extract was analysis using GC-MS (Thermo Trace 1300 GC coupled with Thermo TSQ 800 Triple Quadrupole MS) fitted with a BP 5 MS capillary column (30 $\mathrm{m} \times 0.25 \mathrm{~mm}, 0.25 \mu \mathrm{m}$ film thickness). Injector temperature was $250^{\circ} \mathrm{C}$. The 
column temperature was programmed from $110^{\circ} \mathrm{C}$ to $200^{\circ} \mathrm{C}$, temperatures held for $110^{\circ} \mathrm{C}$ for 2 minutes, gradually increased to $200^{\circ} \mathrm{C}$ at $10^{\circ} \mathrm{C}$ minutes -1 and then $280^{\circ} \mathrm{C}$ at $5{ }^{\circ} \mathrm{C}$ minutes ${ }^{-1}$ kept there for 9 minutes. Helium was used as a carrier gas, at a flow rate of $1.0 \mathrm{ml} \mathrm{minutes}^{-1}$ and mass spectra were recorded in the scan mode. The ionization voltage was $70 \mathrm{eV}$. The split ratio was $10: 1$. The ion source temperature was $230^{\circ} \mathrm{C}$, Interface temperature was $280^{\circ} \mathrm{C}$. Solvent cut time was 3 minutes. For the analysis, $1 \mu \mathrm{lof} 1 \mathrm{mg} \mathrm{ml}^{-1}$ of the sample was used. The constituents of extract were identified based on their retention time (Rt) with respect to the reference. The scan range was $45-450 \mathrm{~m} / \mathrm{z}$. The identification of compounds was based on matching unknown peaks with MS-data bank (NIST 2.0 electronic Library).

\subsection{Molecular docking of B. macrophylla compounds with target protein of $C$. albicans}

2.6.1 Bioinformatics tools: AutoDock Vina (Trott and Olson, 2010) Open Babel GUI (O'Boyle et al. 2011), Molispiration (https://www.molinspiration.com/), PROTOX-II (http://tox.charite.de/protox_II/) and discovery studio and Chimera 1.8.1 were used in this study.

\subsubsection{Retrieval and preparation of target protein}

3-dimentional structure of C. albicans target protein (Cytochrome P450 14 alpha-sterol Demethylase PDB ID: 1EA1) (Podust et al. 2011) were retrieved from protein data bank (https://www.rcsb.org/). Active site was predicted on the basis of previous studies (Rolta et al. 2020C and Salaria et al. 2021).

\subsubsection{Ligand preparation}

Three dimensional structures of $B$. macrophylla compounds such as 1-(3-Hydroxypropyl)-2-piperidinone, 1,3Dioxolane, 5-Keto-D-fructose, 9,9-Dimethoxybicyclo [ 3.3.1] nona-2,4-dione, Benzoic acid, 2-(dimethylamino) ethyl ester, Benzoic acid, 2-(dimethylamino) ethyl ester, N-(1-Methoxycarbonyl-1-methylethyl)-4-methyl-2-aza1,3-dioxane, Sucrose and standard antifungal antibiotic (fluconazole) were retrieved from Pubchem (www.pubchem.com) in .sdf format. Ligand energy was minimized by using chemdraw 3D 15.0 and ligand was prepared by using autodock tool 1.5.6.

\subsubsection{Molecular docking of B. macrophylla compounds with $C$. albicans target}

All the selected ligands (1-(3-Hydroxypropyl)-2-piperidinone, 1,3-Dioxolane, 5-Keto-D-fructose, 9,9Dimethoxybicyclo [ 3.3.1] nona-2,4-dione, Benzoic acid, 2-(dimethylamino) ethyl ester, Benzoic acid, 2(dimethylamino) ethyl ester, N-(1-Methoxycarbonyl-1-methylethyl)-4-methyl-2-aza-1,3-dioxane, Sucrose) were used to perform molecular docking studies with fungal proteins (1EA1) to find the potential drug. In the current research molecular docking was performed by using AutoDock vina (Trott and Olson 2010).

\subsection{Drug likeness calculations of $B$. macrophylla compounds}

The purpose of the drug scan was to see if certain phytochemicals met the drug-likeness criteria. For assessing drug similarity properties such as amount of hydrogen acceptors, Lipinski's filters were used. Drug likeness prediction was done by using online server Molinspiration (http://www.molinspiration.com) were applied for examining drug likeness attributes as including quantity of hydrogen acceptors (should not be more than 10), 
quantity of hydrogen donors (should not be more than 5), molecular weight (mass should be more than 500 daltons) and partition coefficient log P (should not be less than 5). The smiles format of each of the phytochemical was uploaded for the analysis (Rosell and Crino 2002).

\subsection{ADME/T screening and toxicity prediction of $B$. macrophylla compounds}

ADME/T screening was done to determine the absorption, toxicity, and drug-likeness properties of selected phytocompounds. Canonical SMILES of B. macrophylla phytocompounds (1-(3-Hydroxypropyl)-2-piperidinone, 1,3-Dioxolane, 5-Keto-D-fructose, 9,9-Dimethoxybicyclo [3.3.1] nona-2,4-dione, Benzoic acid, 2-(dimethylamino) ethyl ester, Benzoic acid, 2-(dimethylamino) ethyl ester, N-(1-Methoxycarbonyl-1-methylethyl)-4-methyl-2-aza1,3-dioxane, Sucrose) uploaded on PROTOX-II webservers (Charite University of Medicine, Institute for Physiology, Structural Bioinformatics Group, Berlin, Germany). PROTOX is a Rodent oral toxicity server predicting LD50 value and toxicity class of query molecule. The toxicity classes are as follows: (i) Class 1: fatal if swallowed (LD50 $\leq 5)$, (ii) Class 2: fatal if swallowed (55000) (Banerjee et al. 2018).

\section{Result And Discussions}

\subsection{Qualitative and quantitative estimation of phytocompounds in methanolic extract of $B$. macrophylla rhizome}

\subsubsection{Qualitative analysis of phytochemicals}

Methanolic extract of rhizome of B. macrophylla was subjected to phytochemical screening such as alkaloids, flavonoids, phenolic compounds and tannins, carbohydrates, glycosides, steroids, saponins, proteins and amino acids. The qualitative screening revealed the presence of phytocompounds such as phenolics, tannins, flavonoids, carbohydrates, alkaloids and phytosteroids. However, glycosides, terpenoids and saponin were undetectable. Summary of phytochemical screening is shown in Table 1. Previously, Chandra et al. (2016) have also investigated the phytochemicals in various extracts of whole plant of B. macrophylla and reported that alkaloids and phytosteriods were undetectable in methanolic as well as in water extracts. Similar to our study, Chandra et al. (2016) showed the presence of phenolics, tannins, flavonoids, carbohydrates, glycosides, and saponins in methanolic and water extracts. Petroleum ether extract showed the presence of phenolics and tannins only. This variation in phytoconstituents may be possibly due to: 1) difference in geographical locations of the sample collection; sample collection at different time of the year; 3) different genotypes. The results of current study and Chandra et al. (2016) indicate that accumulation of phytocompounds could be affected by geographical location, month of sample collection along with genotype. Nayeem et al. (2017) reported the seasonal and geographic variation in phytoconstituents of Tribules terrestris collected from Rajha, Northern Border province Saudi Arabia and Bangalore, Karnataka, India in summer and winter. Study from Inbathamizh and padmini (2013), suggested the effect of geographical distribution on phytochemical and antioxidant activity of Moringa oleifera flowers. 
Table 1

Summary of phytocompounds present in methanolic extract of rhizome of B. macrophylla.

\begin{tabular}{|c|c|c|}
\hline Phytoconstituents & Tests & Methanolic extract \\
\hline \multirow[t]{2}{*}{ Phenolics and tannin } & Ferric chloride test & + \\
\hline & Gelatin test & + \\
\hline Flavonoids & Lead acetate test & + \\
\hline Carbohydrates & Fehling solution test & + \\
\hline Glycosides & Borntrager test & - \\
\hline Alkaloids & Dragendorff test & + \\
\hline Saponin & Foam test & - \\
\hline Terpenoids & Salkowsky test & - \\
\hline \multicolumn{3}{|c|}{$\begin{array}{l}\text { ' }+ \text { ' indicates the presence and ' } \nabla \text { ' indicates the absence of phytochemicals. The intensity of the colour } \\
\text { produced was taken as an indication of amount of particular phytochemicals present. }\end{array}$} \\
\hline
\end{tabular}

Total phenolic contents (TPC) were determined using Folin-ciocalteau method (Singleton 1999) and the values were expressed as GAE, whereas, total flavonoid content (TFC) was measured by aluminium chloride method (Zhisen et al. 1999) and the values were expressed in terms of RE (rutin equivalent). Bistorta macrophylla rhizome extract was rich in total phenolic content $\left(191.18 \pm 29.18 \mathrm{mg} \mathrm{g}^{-1} \mathrm{GAE}\right)$ as compared to flavonoid content $\left(26.71 \pm 3.21 \mathrm{mg} \mathrm{g}^{-1} \mathrm{RE}\right)$. Our data is in contrast to previous report by Chandra et al. (2016), where they showed that total phenolic and flavonoid content of methanolic extract of Bistorta macrophylla were $76.14 \mathrm{mg}$ $\mathrm{g}^{-1} \mathrm{GAE}$ and $51.55 \mathrm{mg} \mathrm{g}^{-1} \mathrm{RE}$, respectively. Our study showed that phenolic content was almost 2.5 times more, but flavonoid content was half as compared to reports by Chandra et al. (2016). Study from Rosendal et al. (2020) is the evidence of variation in phenolics and flavonoids due to different geographical regions.

3.2 Analysis of antifungal activity of methanolic extract of B. macrophylla rhizome by agar well diffusion and broth dilution method

An antifungal activity assay was performed by using agar well diffusion method and observed as zone of inhibition against the tested fungal strains. Methanolic extract of $B$. macrophylla showed inhibition to growth of fungal strains. Antifungal activity was fungicidal (cell death) against C. albicans (MTCC27 and ATCC90028); whereas fluconazole and amphotericin B were fungi static (growth arrest) against C. albicans (MTCC277 and ATCC90028) shown in Table 2 and figure $3 a$. 
Table 2

Qualitative and quantitative measurement of antifungal activity of methanolic extract of rhizome of $B$. macrophylla using agar well diffusion and MIC assays.

\begin{tabular}{|c|c|c|c|c|c|c|}
\hline \multirow[t]{2}{*}{$\begin{array}{l}\text { Fungal } \\
\text { strains }\end{array}$} & \multicolumn{3}{|c|}{$\begin{array}{l}\text { Zone of inhibition } \\
\text { (ZOI) in mm }\end{array}$} & \multicolumn{3}{|c|}{$\begin{array}{l}\text { Minimum inhibitory concentration (MIC) in } \\
\mu \mathrm{g} / \mathrm{ml}\end{array}$} \\
\hline & $\begin{array}{l}\text { Methanolic } \\
\text { Extract }\end{array}$ & Fluconazole & $\begin{array}{l}\text { Amphotericin } \\
\text { B }\end{array}$ & $\begin{array}{l}\text { Methanolic } \\
\text { Extract }\end{array}$ & Fluconazole & $\begin{array}{l}\text { Amphotericin } \\
\text { B }\end{array}$ \\
\hline $\begin{array}{l}\text { C. albicans } \\
\text { (MTCC277) }\end{array}$ & $\begin{array}{l}17.5 \\
(\star \star)\end{array}$ & $\begin{array}{l}17.5 \\
(*)\end{array}$ & $\begin{array}{l}12 \\
(*)\end{array}$ & 62.5 & 31.25 & 31.25 \\
\hline $\begin{array}{l}\text { C. albicans } \\
\text { (ATCC90028) }\end{array}$ & $\begin{array}{l}17.5 \\
(\star *)\end{array}$ & $\begin{array}{l}17.5 \\
(*)\end{array}$ & $\begin{array}{l}12 \\
(*)\end{array}$ & 62.5 & 15.6 & 31.25 \\
\hline $\begin{array}{l}\text { Double star (** } \\
\text { activity (growtl } \\
\text { inhibitory conc }\end{array}$ & idicates fun & al activity $\mathrm{n}$ & measured as & he of inhibit & $\begin{array}{l}\text { indicates } \mathrm{fl} \\
(\mathrm{mm}) \text { and } \mathrm{m}\end{array}$ & $\begin{array}{l}\text { jistatic } \\
\text { mum }\end{array}$ \\
\hline
\end{tabular}

MIC of methanolic extract of $B$. macrophylla was $62.5 \mu \mathrm{g} \mathrm{ml}^{-1}$ against both fungal strains $C$. albicans (MTCC277 and ATCC 90028). On the other hand, the MIC of fluconazole was found $31.25 \mu \mathrm{g} \mathrm{ml}{ }^{-1}$ against $C$. albicans (MTCC277), and 15.6 $\mathrm{g} \mathrm{ml}^{-1}$ C. albicans (ATCC 90028). The MIC of amphotericin B was $31.25 \mu \mathrm{g}$ $\mathrm{ml}^{-1}$ against both strains of $C$. albicans (MTCC277 and ATCC 90028) (Table 2 and Figure 3b). B. macrophylla rhizomes have been reported for wound healing by local healers of higher altitudes of Uttarakhand, India (Phondani 2011). Also, rhizome and leaves of Bistorta affinis and Bistorta amplexicaulis are known for the treatment of skin irritation, dermatitis, eczema, measles (Rahman et al. 2018).

\subsection{Synergistic enhancement of antifungal activity of fluconazole and amphotericin B against fungal strains}

Methanolic extract of rhizome of B. macrophylla showed synergistic potential with fluconazole and amphotericin $B$ against fungal strains. To analyze the synergistic potential between antifungal antibiotics (fluconazole and amphotericin B) and methanolic extract of rhizome of B. macrophylla, nine combinations based on MIC of antibiotics and methanolic extract of rhizome of B. macrophylla were prepared. Based on the minimum $\mathrm{FICl}$ value, the combination of extract equivalent to $\mathrm{MIC}\left(62.5 \mu \mathrm{g} \mathrm{ml}^{-1}\right)$ and fluconazole equivalent to $1 / 2 \mathrm{MIC}\left(15.625 \mathrm{~g} \mathrm{ml}^{-1}\right)$ and $1 / 2$ MIC of extract $\left(31.25 \mu \mathrm{g} \mathrm{ml}^{-1}\right)$ and $1 / 2 \mathrm{MIC}$ of amphotericin B $\left(15.625 \mu \mathrm{g} \mathrm{ml}{ }^{-1}\right)$ showed best synergistic potential against $C$. albicans (MTCC277). The synergistic combination of methanolic extract and fluconazole enhanced the potency of the fluconazole and methanolic extract by 32 folds against $C$. albicans (MTCC277). The combination of amphotericin B with methanolic extract enhanced the potency of amphotericin B and methanolic extract by 128 folds. Combination of $1 / 2 \mathrm{MIC}$ of extract $\left(31.25 \mu \mathrm{gl}^{-1}\right)$ and $\mathrm{MIC}$ of fluconazole $\left(15.625 \mathrm{~g} \mathrm{ml}^{-1}\right) ;{ }^{1} / 2$ MIC of extract $\left(31.25 \mu \mathrm{g} \mathrm{ml}^{-1}\right)$ and $1 / 2$ MIC of amphotericin B $(15.625 \mu \mathrm{g}$ $\mathrm{ml}^{-1}$ ) showed best combinations against $C$. albicans (ATCC90028) as shown in Table 3 . The synergistic potential of fluconazole in combination with methanolic extract was enhanced by 116 folds and 16 folds for 
methanolic extract. On the other hand, the synergistic potential of amphotericin B in combination with methanolic extract was enhanced by 128 folds for amphotericin B and methanolic extract.

Table 3

FIC index showing synergistic potential of methanolic extract of B. macrophylla against S. cerevisiae (H1086), C. albicans (MTCC277), C. albicans (ATCC90028) with fluconazole and amphotericin B.

\begin{tabular}{|c|c|c|c|c|c|c|c|c|c|}
\hline \multirow[t]{3}{*}{ ME } & \multirow[t]{3}{*}{ Antibiotic } & \multicolumn{8}{|c|}{ Fractional Inhibitory Concentration Index (FICl) } \\
\hline & & \multicolumn{3}{|c|}{ C. albicans (MTCC277) } & \multicolumn{5}{|c|}{ C. albicans (ATCC90028) } \\
\hline & & Ab1 & Fold & Ab2 & Fold & Ab1 & Fold & Ab2 & Fold \\
\hline \multirow[t]{2}{*}{$2 \mathrm{MIC}$} & 2MIC & 0.024 & ME-16 & 0.031 & ME-32 & 0.063 & ME-16 & 0.007 & ME-64 \\
\hline & & & Ab-16 & & Ab-32 & & Ab-16 & & Ab-64 \\
\hline \multirow[t]{2}{*}{$2 \mathrm{MIC}$} & MIC & 0.018 & ME-8 & 0.032 & ME-32 & 0.032 & ME-32 & 0.031 & ME-32 \\
\hline & & & $A b-16$ & & Ab-32 & & Ab-32 & & Ab-32 \\
\hline \multirow[t]{2}{*}{$2 \mathrm{MIC}$} & $\mathrm{MIC} / 2$ & 0.015 & ME-16 & 0.016 & ME-32 & 0.016 & ME-16 & 0.016 & ME-32 \\
\hline & & & $A b-16$ & & Ab-32 & & $A b-16$ & & Ab-32 \\
\hline \multirow[t]{2}{*}{ MIC } & 2MIC & 0.013 & ME-16 & 0.063 & ME-32 & 0.062 & ME-16 & 0.001 & ME-32 \\
\hline & & & $A b-16$ & & Ab-32 & & $A b-16$ & & $A b-32$ \\
\hline \multirow[t]{2}{*}{ MIC } & MIC & 0.001 & ME-16 & 0.031 & ME-32 & 0.062 & ME-8 & 0.31 & ME-32 \\
\hline & & & $A b-16$ & & Ab-32 & & $A b-8$ & & Ab-32 \\
\hline \multirow[t]{2}{*}{ MIC } & $\mathrm{MIC} / 2$ & 0.004 & ME-32 & 0.015 & ME-32 & 0.050 & ME-16 & 0.015 & ME-32 \\
\hline & & & $A b-32$ & & $A b-32$ & & $A b-16$ & & $A b-32$ \\
\hline \multirow[t]{2}{*}{$\mathrm{MIC} / 2$} & $2 \mathrm{MIC}$ & 0.251 & ME-16 & 0.003 & ME-32 & 0.063 & ME-16 & 0.008 & ME-32 \\
\hline & & & $A b-16$ & & $A b-32$ & & $A b-16$ & & $A b-32$ \\
\hline \multirow[t]{2}{*}{$\mathrm{MIC} / 2$} & MIC & 0.252 & ME-8 & 0.032 & ME-32 & 0.031 & ME-16 & 0.032 & ME-32 \\
\hline & & & $A b-8$ & & $A b-32$ & & $A b-16$ & & $A b-32$ \\
\hline \multirow[t]{2}{*}{$\mathrm{MIC} / 2$} & $\mathrm{MIC} / 2$ & 0.013 & ME-8 & 0.0165 & ME-128 & 0.007 & ME-32 & 0.017 & ME-128 \\
\hline & & & $A b-8$ & & Ab-128 & & Ab-32 & & Ab-128 \\
\hline
\end{tabular}

So far, there is no study on the synergistic potential of B. macrophylla extract in the literature against fungal strains. This is the first study to show the antifungal activity of $B$. macrophylla extract. In addition to antifungal activity, methanolic extract of $B$. macrophylla also acts synergistically with antifungal antibiotics (fluconazole and amphotericin B) and increases the potency. The Indian patent application for this study has been submitted (Kashyap et al. 2018) 
Synergistic activity of plant extract and antibiotics were reported in literature and such combinatorial formulations can be considered an alternative to antibiotics for the treatment of multi drug resistant bacterial and fungal pathogens (Yu et al. 2005; Al-Bayati, 2008; Rolta et al. 2018 a,b; Nidhi et al. 2020; Rolta et al. 2020a). Rolta et al. (2020b) reported the synergistic activity of emodin extracted from chloroform fraction of Rheum emodi rhizome extract (methanolic) in combination with antibacterial and antifungal antibiotics. Emodin increases the efficacy of antibiotics 4-257 folds against bacterial and fungal pathogens. Mehta et al. 2021 reported the synergistic activity of ethyl-acetate extracts of $P$. integerrima, $O$. sanctum, $C$. asiatica, $M$. charantia, Z. officinale, and W. somnifera in combination with ciprofloxacin and tetracycline against Salmonella typhimurium. Salaria et al. 2021 reported the synergistic activity of Thymus serpyllum essential oil and thymol against $E$. coli, S. aureus and K. pneumoniae in combination with tetracycline and vancomycin; they also reported the synergistic activity against $C$. albicans (MTCC277 and ATCC 90028) in combination with Fluconazole and amphotericin B by using checkerboard method.

\subsection{GC-MS of methanolic extract of Bistorta macrophylla rhizome}

GC-MS is important technique for the quality evaluation of natural products Yi et al (2017). GC-MS analysis of the methanolic extract of $B$. macrophylla showed the presence of 15 major with peaks with area (\%) corresponding to more than 1 . These phytocompounds were identified by comparing the mass spectra of the constituents with the NIST mass spectral library (https://chemdata.nist.gov/) and are summarized in Table 4. The list of phytocompounds identified in the methanolic extract of $B$. macrophylla is summarized in Table 4 . The profile of mass spectra showing the retention time (RT) and relative abundance of all the phytochemicals identified in the methanolic extract of $B$. macrophylla is shown in Figure 4. The present study is the first report on GC-MS analysis of methanolic rhizome extract of rhizome of B. macrophylla. GC-MS peaks showing more than $1 \%$ relative abundance were analyzed and reported. Among all the phytocompounds, sucrose $(41.07 \%)$, benzoic acid, 2-(dimethylamino) ethyl ester (18.24\%), 9, 9-Dimethoxybicyclo [3.3.1] nona-2, 4-dione (7.11\%) were major constituents. The phytocompounds such as 5-Keto-D-fructose (3.25\%) and sucrose $(41.07 \%)$ have been reported as sweetener agent (Herweg et al. 2018; Tappy et al. 2010) and antidiabetic properties (Wyrobnik and Wyrobnik 2018) Benzoic acid (18.24\%) is known for its antibacterial activity (Park et al. 2001) against Staphylococcus aureus ATCC 6538P, and Pseudomonas aeruginosa ATCC 15522. a-D-Glucopyranoside have reported for its cardioprotective, neuroprotective, antidiabetic and anti-osteoporotic activity (Altameme et al. 2015). Similarly, Ko et al. (2018) reported that linoleic acid, ethyl ester as antimicrobial and anti-inflammatory agents, mention few lines about data, which microbes etc. Decanoic acid (capric acid) is a class of medium chain fatty (MCFA) that are known to create pores in the membranes and impair the cell permeability (Choi et al. 2013) and leakage of the cytoplasmic content, and eventual cell death (Tsuchido et al). 1, 3-Dioxolane derivatives have been reported for antibacterial and antifungal activity against $S$. aureus, Staphylococcus epidermidis, Pseudomonas aeruginosa and against a yeast Candida albicans ATCC 10231 (Küçük et al. 2011). Similarly, antimicrobial activity of organic-inorganic hybrid films based on gelatin and organomodified silicones (Heptamethyltrisiloxane) have been reported by Wojciechowska et al. (2018). Either alone or in combination, these phytocompounds present in the rhizome extract of $B$. macrophylla could be responsible for antifungal activity, antioxidant activity, and enhancing the potency of fluconazole and amphotericin B. 
Table 4

Summary of compounds indentified in methanolic extract of B. macrophylla through GC-MS analysis.

\begin{tabular}{|c|c|c|c|}
\hline Compound name/CID & $\begin{array}{l}\text { RT } \\
\text { (min)/Area } \\
\%\end{array}$ & $\begin{array}{l}\text { Molecular } \\
\text { formula }\end{array}$ & $\begin{array}{l}\text { Pharmacological } \\
\text { properties }\end{array}$ \\
\hline 5-Keto-D-fructose /99513 & $3.40 / 3.25$ & $\mathrm{C}_{6} \mathrm{H}_{12} \mathrm{O}_{6}$ & $\begin{array}{l}\text { Sweetener agent and antidiabetic } \\
\text { (Herweg et al. 2018; Wyrobnik and } \\
\text { Wyrobnik 2018) }\end{array}$ \\
\hline $\begin{array}{l}\mathrm{N}-(1-M e t h o x y c a r b o n y l-1- \\
\text { methylethyl)-4-methyl-2-aza-1,3- } \\
\text { dioxane /588924 }\end{array}$ & $4.49 / 1.48$ & $\mathrm{C}_{6} \mathrm{H}_{12} \mathrm{~N}_{2} \mathrm{~S}$ & No activity reported \\
\hline $\begin{array}{l}\text { 1-(3-Hydroxypropyl)-2- } \\
\text { piperidinone/574874 }\end{array}$ & $5.34 / 0.77$ & $\mathrm{C}_{4} \mathrm{H}_{4} \mathrm{~N}_{4} \mathrm{O}_{3}$ & No activity reported \\
\hline a-D-Glucopyranoside/95143 & $5.88 / 1.43$ & $\mathrm{C}_{18} \mathrm{H}_{32} \mathrm{O}_{16}$ & $\begin{array}{l}\text { Cardioprotective, neuroprotective, } \\
\text { antidiabetic and anti-osteoporotic } \\
\text { activities (Altameme et al., 2015). }\end{array}$ \\
\hline $\begin{array}{l}\text { Cyclohexasiloxane, } \\
\text { dodecamethyl/10911 }\end{array}$ & $6.43 / 1.14$ & $\mathrm{C}_{22} \mathrm{H}_{48} \mathrm{OSi}$ & No activity reported \\
\hline Sucrose/5988 & $\begin{array}{l}8.51 \\
/ 41.07\end{array}$ & $\mathrm{C}_{12} \mathrm{H}_{22} \mathrm{O}_{11}$ & $\begin{array}{l}\text { Sweetener agent (Tappy et al., } \\
\text { 2010) }\end{array}$ \\
\hline Silane /23953 & $\begin{array}{l}10.65 / \\
6.75\end{array}$ & $\mathrm{C}_{23} \mathrm{H}_{42} \mathrm{~F}_{3} \mathrm{NO}_{4} \mathrm{Si}_{3}$ & No activity reported \\
\hline Decanoic acid/13225435 & $\begin{array}{l}14.19 \\
/ 1.66\end{array}$ & $\mathrm{C}_{11} \mathrm{H}_{22} \mathrm{O}_{2}$ & Antimicrobial activity reported \\
\hline Octasiloxane /4080431 & $\begin{array}{l}14.43 \\
/ 0.47\end{array}$ & $\mathrm{C}_{16} \mathrm{H}_{50} \mathrm{O}_{7} \mathrm{Si}_{8}$ & No activity reported \\
\hline $\begin{array}{l}\text { Benzoic acid, 2- } \\
\text { (dimethylamino)ethyl ester } \\
\text { /75158 }\end{array}$ & $\begin{array}{l}14.59 \\
/ 18.24\end{array}$ & $\mathrm{C}_{10} \mathrm{H}_{15} \mathrm{~N}$ & $\begin{array}{l}\text { Antibacterial activity (Park et al., } \\
\text { 2001), antimicrobial additive in } \\
\text { foods(Park et al., 2001) }\end{array}$ \\
\hline Linoleic acid ethyl ester / 5282184 & $\begin{array}{l}16.56 \\
/ 1.08\end{array}$ & $\mathrm{C}_{20} \mathrm{H}_{36} \mathrm{O}_{2}$ & $\begin{array}{l}\text { Antibacterial and anti- } \\
\text { inflammatory (Ko et al., 2018) }\end{array}$ \\
\hline $\begin{array}{l}\text { 9,9-Dimethoxybicyclo [ } 3.3 .1] \\
\text { nona-2,4-dione /537288 }\end{array}$ & $\begin{array}{l}17.22 \\
/ 7.11\end{array}$ & $\mathrm{C}_{18} \mathrm{H}_{34} \mathrm{O}_{2}$ & No activity Reported \\
\hline 1,3-Dioxolane /12586 & $\begin{array}{l}26.04 \\
/ 3.61\end{array}$ & $\mathrm{C}_{22} \mathrm{H}_{38} \mathrm{O}_{4}$ & $\begin{array}{l}\text { Antibacterial and antifungal } \\
\text { activity (Hatice et al, see belwo). }\end{array}$ \\
\hline $\begin{array}{l}\text { 1,1,1,3,5,5,5- } \\
\text { Heptamethyltrisiloxane/ } 6327366\end{array}$ & $\begin{array}{l}26.55 \\
/ 1.57\end{array}$ & $\mathrm{C}_{16} \mathrm{H}_{50} \mathrm{O}_{7} \mathrm{Si}_{8}$ & $\begin{array}{l}\text { Antimicrobial activity reported } \\
\text { (Wojciechowska et al., 2017) }\end{array}$ \\
\hline Hexasiloxane/87782 & $\begin{array}{l}28.95 \\
/ 1.49\end{array}$ & $\mathrm{C}_{12} \mathrm{H}_{38} \mathrm{O}_{5} \mathrm{Si}_{6}$ & No activity Reported \\
\hline
\end{tabular}

\subsection{Molecular docking of $B$. macrophylla compounds with $C$. albicans target protein}


Molecular docking was performed to study the interactions of identified phytocompounds in methanolic extract of B. macrophylla of with Cytochrome P450 14 alpha-sterol demethylase (1EA1). Molecular docking was performed by autoDock vina software.

Docking results showed that among all the selected compounds of $B$. macrophylla sucrose showed the highest binding energy $(-6.3 \mathrm{KJ} / \mathrm{mol})$ followed by 9,9-Dimethoxybicyclo [3.3.1] nona-2,4-dione $(-5.1 \mathrm{KJ} / \mathrm{mol})$, Cyclohexasiloxane, dodecamethyl (-4.9 KJ/mol), N-(1-Methoxycarbonyl-1-methylethyl)-4-methyl-2-aza-1,3dioxane (-4.8 KJ/mol), 1-(3-Hydroxypropyl)-2-piperidinone (-4.5 KJ/mol), Benzoic acid, 2-(dimethylamino) ethyl ester (-4.4 KJ/mol), 5-Keto-D-fructose $(-4.3 \mathrm{KJ} / \mathrm{mol})$ and 1,3-Dioxolane $(-2.6 \mathrm{KJ} / \mathrm{mol})$. Sucrose makes hydrogen bonds with GLU, ARG, HIS, TYR at positions 271, 274, 275, 426 respectively, Sucrose also showed hydrophobic interactions with TRP, LEU, HIS, HIS, PHE, GLU, ARG at position 267, 317, 318, 363, 365, 424, 427 respectively. Interactive amino acids are shown in Table 5 and Figure 5. 3D structures of protein ligand complexes are shown in Figure 6. Furthermore, all the selected phytocompounds were screened for drug likeness and ADME/T. Similar to our study, Kumar et al. (2020); Nidhi et al. (2020); Rolta et al. (2020) and Salaria et al. (2021) studied the molecular docking of Rheum emodi phytocompounds with fungal target 1EA1 (Cytochrome P450 14 alphasterol demethylase CYP51). 
Table 5

E-total, Hydrogen bonding and interacting amino acids of Phytocompounds of B. macrophylla in complex with 1EA1

\begin{tabular}{|c|c|c|c|}
\hline \multirow[t]{2}{*}{ Compounds/Drugs } & \multicolumn{3}{|l|}{ 1EA1 } \\
\hline & $\begin{array}{l}\text { Affinity } \\
\text { (kcal/mol) }\end{array}$ & H-bonding & Interactive amino acids \\
\hline $\begin{array}{l}\text { 1-(3-Hydroxypropyl)-2- } \\
\text { piperidinone }\end{array}$ & -4.5 & ARG 354 & $\begin{array}{l}\text { ILE 27, TRP 267, LEU 317, HIS 318, PRO 319, } \\
\text { ALA 350, ARG 427, ASN 428, HIS } 430\end{array}$ \\
\hline 1,3-Dioxolane & -2.6 & ARG 274 & GLU 271, LEU 317, HIS 363, ASP 364, PHE 365 \\
\hline 5-Keto-D-fructose & -4.3 & $\begin{array}{l}\text { ARG 23, } \\
\text { ARG } 427\end{array}$ & $\begin{array}{l}\text { THR 24, ASP 25, PRO 26, ILE 27, ASN 428, ASP } \\
\text { 429, SER 431, }\end{array}$ \\
\hline $\begin{array}{l}\text { 9,9-Dimethoxybicyclo [ } \\
\text { 3.3.1] nona-2,4-dione }\end{array}$ & -5.1 & $\begin{array}{l}\text { ARG } 274 \\
\text { ARG } 354\end{array}$ & $\begin{array}{l}\text { TRP 267, HIS 318, TYR 426, ARG 427, ASN 428, } \\
\text { HIS } 430\end{array}$ \\
\hline $\begin{array}{l}\text { Benzoic acid, 2- } \\
\text { (dimethylamino) ethyl } \\
\text { ester }\end{array}$ & -4.4 & $\begin{array}{l}\text { ARG } 274 \\
\text { AGR } 354\end{array}$ & $\begin{array}{l}\text { TRP 267, HIS 275, GLU 271, LEU 317, HIS 318, } \\
\text { HIS 363, ASP 364, PHE 365, TYR 426, ARG 427, } \\
\text { ASN } 428\end{array}$ \\
\hline $\begin{array}{l}\text { Cyclohexasiloxane, } \\
\text { dodecamethyl }\end{array}$ & -4.9 & ARG 354 & $\begin{array}{l}\text { ILE 27, TRP 267, LEU 317, HIS 318, HIS 363, GLU } \\
424, \text { ARG 427, ASN 428, HIS } 430\end{array}$ \\
\hline $\begin{array}{l}\mathrm{N}-(1-\text { Methoxycarbonyl-1- } \\
\text { methylethyl)-4-methyl-2- } \\
\text { aza-1,3-dioxane }\end{array}$ & -4.8 & AGR 354 & $\begin{array}{l}\text { ILE 27, ARG 274, LEU 317, HIS 318, PRO 319, ILE } \\
322, \text { ALA 350, ASN 428, HIS } 430\end{array}$ \\
\hline Sucrose & -6.3 & $\begin{array}{l}\text { GLU 271, } \\
\text { ARG 274, } \\
\text { HIS 275, } \\
\text { TYR } 426\end{array}$ & $\begin{array}{l}\text { TRP 267, LEU 317, HIS 318, HIS 363, PHE 365, } \\
\text { GLU 424, ARG 427 }\end{array}$ \\
\hline Fluconazole & -7.2 & ARG 96 & $\begin{array}{l}\text { LEU 100, PHE 255, HIS 255, HIS 259, VAL 434, } \\
\text { MET 433, PHE 78, LEU 321, TYR 76, GLN 72, HIS } \\
\text { 392, PHE 83, ALA 256, MET } 79\end{array}$ \\
\hline
\end{tabular}

\subsection{Drug-likeness prediction of $B$. macrophylla compounds}

Drug-likeness of B. macrophylla compounds was predicted by using Molinspiration (server) which is based on Lipinski rule of 5. Except Octasiloxane and hexasiloxane all other compounds follow the Lipinski's rule of. Whereas Sucrose, Linoleic acid ethyl ester and 1,1,1,3,5,5,5-Heptamethyltrisiloxane showed one violation which is acceptable (Table 6). 
Table 6

Drug likeness prediction of $B$. macrophylla phytocompounds

\begin{tabular}{|c|c|c|c|c|c|c|c|}
\hline Phytocompounds & miLogP & TPSA & natoms & MW & nON & nOHNH & nviolations \\
\hline 5-Keto-D-fructose & -3.90 & 115.05 & 12 & 178.14 & 6 & 4 & 0 \\
\hline $\begin{array}{l}\text { N-(1-Methoxycarbonyl-1- } \\
\text { methylethyl)-4-methyl-2-aza- } \\
\text { 1,3-dioxane }\end{array}$ & 1.43 & 48.01 & 14 & 203.04 & 5 & 0 & 0 \\
\hline $\begin{array}{l}\text { 1-(3-Hydroxypropyl)-2- } \\
\text { piperidinone }\end{array}$ & 0.21 & 40.54 & 11 & 157.21 & 3 & 1 & 0 \\
\hline a-D-Glucopyranoside & 0 & 55.40 & 17 & 250.29 & 6 & 0 & 0 \\
\hline $\begin{array}{l}\text { Cyclohexasiloxane, } \\
\text { dodecamethyl }\end{array}$ & 2.24 & 55.40 & 24 & 444.93 & 6 & 0 & 0 \\
\hline Sucrose & -3.75 & 189.53 & 23 & 342.30 & 10 & 8 & 1 \\
\hline Silane & 1.12 & 0 & 1 & 32.12 & 0 & 0 & 0 \\
\hline Decanoic acid & 8.76 & 26.30 & 29 & 410.67 & 2 & 0 & 1 \\
\hline Octasiloxane & 9.02 & 142.03 & 61 & 987.71 & 13 & 2 & 3 \\
\hline $\begin{array}{l}\text { Benzoic acid, 2- } \\
\text { (dimethylamino)ethyl ester }\end{array}$ & 2.14 & 29.54 & 14 & 193.25 & 3 & 0 & 0 \\
\hline Linoleic acid ethyl ester & 7.54 & 26.30 & 2 & 308.51 & 2 & 0 & 1 \\
\hline $\begin{array}{l}\text { 9,9-Dimethoxybicyclo [ 3.3.1] } \\
\text { nona-2,4-dione }\end{array}$ & 0.45 & 52.61 & 15 & 212.25 & 4 & 0 & 0 \\
\hline 1,3-Dioxolane & 0.13 & 18.47 & 5 & 74.08 & 2 & 0 & 0 \\
\hline $\begin{array}{l}1,1,1,3,5,5,5- \\
\text { Heptamethyltrisiloxane }\end{array}$ & 5.51 & 18.47 & 12 & 221.50 & 2 & 0 & 1 \\
\hline Hexasiloxane & 4.80 & 175.45 & 53 & 879.37 & 19 & 0 & 2 \\
\hline
\end{tabular}

\subsection{Toxicity prediction of $B$. macrophylla compounds}

Toxicity of $B$. macrophylla compounds was predicted with the help of PROTOX-II server, toxicity results are summarized in Table 7. Hepato-toxicity was found in active in all the selected compound, Carcino-genecity was active only N-(1-Methoxycarbonyl-1-methylethyl)-4-methyl-2-aza-1,3-dioxane, Hexasiloxane, Silane, Linoleic acid ethyl ester and 1,3-Dioxolane, immunetoxicity was found inactive in all the selected compounds, Mutagenicity was active only in N-(1-Methoxycarbonyl-1-methylethyl)-4-methyl-2-aza-1,3-dioxane, Cytotoxicity was inactive in all the selected compounds of B. macrophylla (Table 7). Similar to our study, Rolta et al. 2020c analyse the drug likeness and toxicity of Rheum emodin phytocompounds by using Molinspiration and PROTOX-II server, Similarly, Salaria et al. 2020 studied the toxicity of Thymus serpy/lum phytocompounds by using PROTOX-II server. In literature several of insilico drug likeness and toxicity was predicted by using Molinspiration and PROTOX-II server Supandi et al. 2018; Ghosh et al. 2019 and Tolosa et al. 2020. 
Table 7

Toxicity prediction of B. macrophylla phytocompounds

\begin{tabular}{|c|c|c|c|c|c|c|}
\hline \multirow[t]{2}{*}{ Phytocompounds } & \multicolumn{6}{|l|}{ Protox-II } \\
\hline & $\begin{array}{l}\text { LD50 } \\
(\mathrm{mg} / \mathrm{kg})\end{array}$ & Hepatotoxicity & $\begin{array}{l}\text { Carcino- } \\
\text { genecity }\end{array}$ & $\begin{array}{l}\text { Immuno } \\
\text { toxicity }\end{array}$ & $\begin{array}{l}\text { Muta- } \\
\text { genicity }\end{array}$ & $\begin{array}{l}\text { Cyto- } \\
\text { toxicity }\end{array}$ \\
\hline \multirow[t]{2}{*}{ 5-Keto-D-fructose } & 23000 & Inactive & Inactive & Inactive & Inactive & Inactive \\
\hline & $\begin{array}{l}\text { (class } \\
6 \text { ) }\end{array}$ & & & & & \\
\hline \multirow{2}{*}{$\begin{array}{l}\mathrm{N} \text {-(1-Methoxycarbonyl-1- } \\
\text { methylethyl)-4-methyl-2-aza-1,3- } \\
\text { dioxane }\end{array}$} & 2492 & Inactive & Active & Inactive & Active & Inactive \\
\hline & $\begin{array}{l}\text { (Class } \\
5)\end{array}$ & & & & & \\
\hline \multirow{2}{*}{$\begin{array}{l}\text { 1-(3-Hydroxypropyl)-2- } \\
\text { piperidinone }\end{array}$} & 41 & Inactive & Inactive & Inactive & Inactive & Inactive \\
\hline & $\begin{array}{l}\text { (Class } \\
2 \text { ) }\end{array}$ & & & & & \\
\hline \multirow[t]{2}{*}{ a-D-Glucopyranoside } & 648 & Inactive & Inactive & Inactive & Inactive & Inactive \\
\hline & $\begin{array}{l}\text { (Class } \\
3 \text { ) }\end{array}$ & & & & & \\
\hline \multirow{2}{*}{$\begin{array}{l}\text { Cyclohexasiloxane, } \\
\text { dodecamethyl }\end{array}$} & 1540 & Inactive & Inactive & Inactive & Inactive & Inactive \\
\hline & $\begin{array}{l}\text { (Class } \\
4)\end{array}$ & & & & & \\
\hline \multirow[t]{2}{*}{ Sucrose } & 29700 & Inactive & Inactive & Inactive & Inactive & Inactive \\
\hline & $\begin{array}{l}\text { (Class } \\
6)\end{array}$ & & & & & \\
\hline \multirow[t]{2}{*}{ Silane } & 3160 & Inactive & Active & Inactive & Inactive & Inactive \\
\hline & $\begin{array}{l}\text { (Class } \\
5)\end{array}$ & & & & & \\
\hline \multirow[t]{2}{*}{ Decanoic acid } & 10000 & Inactive & Inactive & Inactive & Inactive & Inactive \\
\hline & $\begin{array}{l}\text { (Class } \\
6 \text { ) }\end{array}$ & & & & & \\
\hline \multirow[t]{2}{*}{ Octasiloxane } & 1540 & Inactive & Inactive & Inactive & Inactive & Inactive \\
\hline & $\begin{array}{l}\text { (Class } \\
4)\end{array}$ & & & & & \\
\hline \multirow{2}{*}{$\begin{array}{l}\text { Benzoic acid, 2- } \\
\text { (dimethylamino)ethyl ester }\end{array}$} & 460 & Inactive & Inactive & Inactive & Inactive & Inactive \\
\hline & $\begin{array}{l}\text { (Class } \\
4)\end{array}$ & & & & & \\
\hline
\end{tabular}




\begin{tabular}{|c|c|c|c|c|c|c|}
\hline \multirow[t]{2}{*}{ Phytocompounds } & \multicolumn{6}{|l|}{ Protox-II } \\
\hline & $\begin{array}{l}\text { LD50 } \\
(\mathrm{mg} / \mathrm{kg})\end{array}$ & Hepatotoxicity & $\begin{array}{l}\text { Carcino- } \\
\text { genecity }\end{array}$ & $\begin{array}{l}\text { Immuno } \\
\text { toxicity }\end{array}$ & $\begin{array}{l}\text { Muta- } \\
\text { genicity }\end{array}$ & $\begin{array}{l}\text { Cyto- } \\
\text { toxicity }\end{array}$ \\
\hline Linoleic acid ethyl ester & $\begin{array}{l}20000 \\
\text { (Class } \\
6 \text { ) }\end{array}$ & Inactive & Active & Inactive & Inactive & Inactive \\
\hline $\begin{array}{l}\text { 9,9-Dimethoxybicyclo [3.3.1] } \\
\text { nona-2,4-dione }\end{array}$ & $\begin{array}{l}5000 \\
\text { (Class } \\
5)\end{array}$ & Inactive & Inactive & Inactive & Inactive & Inactive \\
\hline 1,3-Dioxolane & $\begin{array}{l}3000 \\
\text { (Class } \\
5)\end{array}$ & Inactive & Active & Inactive & Inactive & Inactive \\
\hline $\begin{array}{l}1,1,1,3,5,5,5- \\
\text { Heptamethyltrisiloxane }\end{array}$ & $\begin{array}{l}24134 \\
\text { (Class } \\
6 \text { ) }\end{array}$ & Inactive & Inactive & Inactive & Inactive & Inactive \\
\hline Hexasiloxane & $\begin{array}{l}9280 \\
\text { (Class } \\
6 \text { ) }\end{array}$ & Inactive & Active & Inactive & Inactive & Inactive \\
\hline
\end{tabular}

\section{Conclusion}

This is the first report on systematic study of methanolic extract of $B$. macrophylla and showed antifungal activity. Methanolic extract also increased potency of fluconazole and amphotericin B by 8-128 folds. Hence combinatorial formulations of methanolic extract of B. macrophylla and low dosage of fluconazole and amphotericin B could be potentially used for the treatment of fluconazole and amphotericin B resistant candidiasis. GC-MS studies showed interesting findings that, major phytocompounds detected were rare sugars and their derivatives, SCFA and others phytocompounds have been reported in the literature for antimicrobial properties and food preservation properties.

\section{Declarations}

Author's contribution: All the experiments were performed by Ms. Shiwani Shukla, Ms. Anjali Kashyap and Er. Rajan Rolta. Dr. Vikas Kumar provided technical inputs. Dr Anuradha Sourirajan and Dr Kamal Dev conceived the idea and provided guidance to execute the research project.

Conflict of interest: The authors declare that they have no conflicts of interest.

Acknowledgements: The authors acknowledge Shoolini University, Solan, for providing infrastructure support to conduct the research work. Authors also acknowledge the support provided by Yeast Biology Laboratory, 
School of Biotechnology, Shoolini University, Solan, India, Authors also acknowledge Tridev Aushadhi Utpadhan Society Rohal, Shimla, Himachal Pradesh.

\section{References}

1. Abe M, Abe K, Iwabuchi K, Domoto C, Arai S. 1994. Corn Cystatin I Expressed in Escherichia coli: Investigation of Its Inhibitory Profile and Occurrence in Corn Kernels. J Biochem. 116(3):488-492.

2. Al-Bayati FA. 2008. Synergistic antibacterial activity between Thymus vulgaris and Pimpinella anisum essential oils and methanol extracts. J. Ethnopharmacol. 116:403-406.

3. Altameme HJ, Hameed IH, Abu-Serag NA. 2015. Analysis of bioactive phytochemical compounds of two medicinal plants, Equisetum arvense and Alchemila valgaris seed using gas chromatographymass spectrometry and fourier-transform infrared spectroscopy. Malays Appl. Biol. 44; 47-58.

4. Banerjee P, Eckert AO, Schrey AK, Preissner R, 2018. ProTox-Il: a webserver for the prediction of toxicity of chemicals. Nuc. Acids Res. 46(W1): W257-W263.

5. Bonapace CR, Bosso JA, Friedrich LV, White RL, 2002. Comparison of methods of interpretation of checkerboard synergy testing. Diagn Microbiol. Infect. Dis. 44: 363-366.

6. Borges A, Ferreira C, Saavedra MJ, Simoes M, 2013. Antibacterial activity and mode of action of ferulic and gallic acids against pathogenic bacteria. Microb. Drug Resist. 19; 256-265.

7. Chandra S, Saklani S, Mishra AP, Agrawal RK. 2016. In vitro antioxidant activity and phytochemical screening of Garhwal Himalaya medicinal plants. Int. J. Med. Res. Health Sciences 5:35-43.

8. Chauhan NS, 1999. Medicinal and aromatic plants of Himachal Pradesh. Indus publishing.

9. Chauhan PP, Nigam A, Santvan VK. 2020. Ethnobotanical Uses of Medicinal Plants Among the Rural People of Pabbar Valley in District Shimla, Himachal Pradesh, India. Plant Arch. 20: 3707-37019.

10. Choi M, Kim S, Lee N, Rhee M. 2013. New decontamination method based on caprylic acid in combination with citric acid or vanillin for eliminating Cronobacter sakazakii and Salmonella enterica as serovar Typhimurium in reconstituted infant formula. Int. J. Food Microbiol. 166: 499-507.

11. Davidson-Hunt I. 2000. Ecological ethnobotany: stumbling toward new practices and paradigms. MASA J. 16: 1-13.

12. de Freitas Araújo MG, Hilário F, Vilegas W, Dos Santos LC, Brunetti IL, Sotomayor CE, Bauab TM. 2012. Correlation among antioxidant, antimicrobial, hemolytic, and antiproliferative properties of Leiothrix spiralis leaves extract. Int. J. Mol. Sci.13: 9260-9277.

13. Dev K, Kumar V, Rolta R, Sharma A. 2017. Herbal Pharmaceutical Excipient for Enhancing Antifungal and Antibacterial Properties of Existing Drugs, Indian Patent Filing Number: 201711028454.

14. Dudhatra GB. Mody SK, Awale MM, Patel HB, Modi CM, Kumar A, Kamani DR, Chauhan BN. 2012. A comprehensive review on pharmacotherapeutics of herbal bioenhancers. Sci. World J. 2012.

15. Eumkeb G, Siriwong S, Thumanu K. 2012. Synergistic activity of luteolin and amoxicillin combination against amoxicillin-resistant Escherichia coli and mode of action. J. Photoch. Photobio. B. Biol. 117, 247253. 
16. Falowo AB, Muchenje V, Hugo A, Aiyegoro OA, Fayemi PO. 2017. Antioxidant activities of Moringa oleifera L. and Bidens pilosa L. leaf extracts and their effects on oxidative stability of ground raw beef during refrigeration storage. CyTA-J. Food. 15: 249-256.

17. Farnsworth NR. 1988. Screening plants for new medicines. Biodivers. 15: 81-99.

18. Gaur, R.D., 1999. Flora of the District Garhwal, North West Himalaya. Transmedia.

19. Ghosh S, Tripathi P, Talukdar P, Talapatra SN. 2019. In silico study by using ProTox-II webserver for oral acute toxicity, organ toxicity, immunotoxicity, genetic toxicity endpoints, nuclear receptor signalling and stress response pathways of synthetic pyrethroids. World Scien. News. 132: 35-51.

20. Gould IM, Bal AM, 2013. New antibiotic agents in the pipeline and how they can help overcome microbial resistance. Virulence. 4: 185-191.

21. Helmerhorst EJ, Reijnders IM, van't Hof W, Simoons-Smit I, Veerman EC, Amerongen AVN, 1999. Amphotericin B-and Fluconazole-Resistant Candida spp., Aspergillus fumigatus, and Other Newly Emerging Pathogenic Fungi Are Susceptible to Basic Antifungal Peptides. Antimicrob. Agents Chemother.43: 702-704.

22. Herweg E, Schöpping M, Rohr K, Siemen A, Frank O, Hofmann T, Deppenmeier U, Büchs J. 2018. Production of the potential sweetener 5-ketofructose from fructose in fed-batch cultivation with Gluconobacter oxydans. Bioresour. Tech. 259: 164-172.

23. Inbathamizh L, Padmini E. 2013. Effect of geographical properties on the phytochemical composition and antioxidant potential of Moringa oleifera flowers. BioMedRx. 230-24.

24. Kashyap A, Shukla S, Rolta R, Kumar V, Sourirajan A, Dev K. 2018. Rhizome extract of Bistorta macrophylla enhanced the antifungal activity of fluconazole and amphotericin B and method thereof, Indian Patent Filing Number:201811022736.

25. Khandelwal K. 2008. Practical pharmacognosy. Pragati Books Pvt. Ltd.

26. Ko GA, Kim Cho S. 2018. Ethyl linoleate inhibits a-MSH-induced melanogenesis through Akt/GSK3 $\beta / \beta-$ catenin signal pathway. Korean J. Physiol. Pharmacol. 22:53-61.

27. Küçük HB, Yusufoğlu A, Mataracı E, Döşler S. 2011. Synthesis and biological activity of new 1, 3dioxolanes as potential antibacterial and antifungal compounds. Molecules. 16: 6806-6815.

28. Kumar R, Sharma N, Rolta R, Lal UR, Sourirajan A, Dev K, Kumar V. 2020. Thalictrum foliolosum DC: An unexplored medicinal herb from north western Himalayas with potential against fungal pathogens and scavenger of reactive oxygen species. Biocat. Agri. Biotech. 26: 101621.

29. Lockhart SR, Etienne KA, Vallabhaneni S, Farooqi J, Chowdhary A, Govender NP, AL, Calvo B, Cuomo CA, Desjardins CA, Berkow EL. 2016. Simultaneous emergence of multidrug-resistant Candida auris on 3 continents confirmed by whole-genome sequencing and epidemiological analyses. Clin. Infect. Dis. 64:134-140.

30. López-Martínez R. 2010. Candidosis, a new challenge. Clin. Dermatol. 28:178-184.

31. Mehta J, Rolta R, Dev K. 2021. Role of medicinal plants from North Western Himalayas as an efflux pump inhibitor against MDR AcrAB-TolC Salmonella enterica serovar typhimurium: In vitro and In silico studies. J. Ethanopharma. 114589. https://doi.org/10.1016/j.jep.2021.114589. 
32. Mothana RA, Lindequist U. 2005. Antimicrobial activity of some medicinal plants of the island Soqotra. J. Ethnopharmacol. 96: 177-181.

33. Munita JM, Arias CA. 2016. Mechanisms of antibiotic resistance In: Kudva IT, Cornick NA, Plummer PJ, Zhang Q, Nicholson TL, Bannantine JP, Bellaire BH, editors. Virulence Mechanisms of Bacterial Pathogens. 481-511.

34. Nayeem N, Imran M, El-Feky SA. 2017. Effect of seasonal and geographical variation on the phytoconstituents and medicinal properties of Tribulus Terrestris. Indo Am. J. Pharm. 4: 1045-1051.

35. Nidhi P, Rolta R, Kumar V, Dev K, Sourirajan A. 2020. Synergistic potential of Citrus aurantium L. essential oil with antibiotics against Candida albicans. J. Ethnopharmacol. 113135.

36. O'Boyle NM, Banck M, James CA, Morley C, Vandermeersch T, Hutchison GR. 2011. Open Babel: An open chemical toolbox. J. Cheminfo. 3: 1-14.

37. Park ES, Moon WS, Song MJ, Kim MN, Chung KH, Yoon JS, 2001. Antimicrobial activity of phenol and benzoic acid derivatives. Int. Biodeterior. Biodegradation. 47: 209-214.

38. Perez C. 1990. Antibiotic assay by agar-well diffusion method. Acta Biol. Med. Exp. 15:113-115.

39. Phondani PC. 2011. Worth of traditional herbal system of medicine for curing ailments prevalent across the mountain region of Uttarakhand, India. J. Appl. Pharma Sci. 1: 81-86.

40. Podust LM, Poulos TL, Waterman MR. 2001. Crystal Structure of Cytochrome P450 14Alpha -Sterol Demethylase (Cyp51) from Mycobacterium tuberculosis in Complex with Azole Inhibitors Proc. Natl. Acad. Sci. U. S. A. 98: 3068.

41. Rahman IU, Afzal A, Iqbal Z, ljaz F, Ali N, Bussmann RW. 2018 Traditional and ethnomedicinal dermatology practices in Pakistan Clin. Dermatol. 36: 310-319.

42. Rios JL, Recio MC. 2005. Medicinal plants and antimicrobial activity. J. Ethnopharmacol. 100: 80-84.

43. Rolta R, Kumar V, Sourirajan A, Upadhyay NK, Dev K. 2020b. Phytocompounds of three medicinal plants (Juniperus Communis, Urtica dioica and Coleus forskohlii) of North West Himalayas increases the potency of antibacterial and antifungal antibiotics. Plant Arch. 20: 481-489.

44. Rolta R, Kumar V, Sourirajan A, Upadhyay NK, Dev K. 2020a. Bioassay guided fractionation of rhizome extract of Rheum emodi wall as bio-availability enhancer of antibiotics against bacterial and fungal pathogens. J. Ethnopharmacol. 257: e112867.

45. Rolta R, Salaria D, Kumar V, Patel CN, Sourirajan A, Baumler DJ, Dev K. 2020C. Molecular docking studies of phytocompounds of Rheum emodi Wall with proteins responsible for antibiotic resistance in bacterial and fungal pathogens: in silico approach to enhance the bio-availability of antibiotics. J. Biomol. Struct. Dynam. 1-15.

46. Rolta R, Sharma A, Kumar V, Chauhan PK, Sourirajan A, Dev K. (2018b) Traditional Medicinal Plants of Higher Altitude of Himachal Pradesh as Functional Food Ingredient Cum Food Preservative and Bioavailability Enhancer of Antifungal Antibiotics. In International Conference on New Horizons in Green Chemistry \& Technology (ICGCT).

47. Rolta R, Sharma A, Kumar V, Sourirajan A, Baumler DJ, Dev K. 2018a. Methanolic Extracts of the Rhizome of $R$. emodi Act as Bioenhancer of Antibiotics against Bacteria and Fungi and Antioxidant Potential. Med. Plant Res. 8: 74-85. 
48. Rosell R, Crinó L. 2002. Pemetrexed combination therapy in the treatment of non-small cell lung cancer. In Sem. Oncol. 29: 23-29.

49. Rosendal E, Ou \& edraogo JCW, Dicko C, Dey ES, Bonzi-Coulibaly YL. 2020. Geographical variation in total phenolics, flavonoids and antioxidant activities of Eucalyptus camaldulensis leaves in Burkina Faso. Afr. J. Pure Appl. Chem. 14: 51-59.

50. Salaria D, Rolta R, Patel CN, Dev K, Sourirajan A, Kumar V. 2021. In vitro and in silico analysis of Thymus serpyllum essential oil as bioactivity enhancer of antibacterial and antifungal agents. J. Biomol. Struct. Dynam.1-20.

51. Samant SS, Dhar U. 1997. Diversity, endemism and economic potential of wild edible plants of Indian Himalaya. Int. J. Sust. Dev. World. 4: 179-191.

52. Samant SS, Dhar U, Palni LMS. 1998. Medicinal Plants of Indian Himalaya. Gyanodaya Prakashan.

53. Satoh K, Makimura K, Hasumi Y, Nishiyama Y, Uchida K, Yamaguchi, H. 2009 Candida auris sp. nov., a novel ascomycetous yeast isolated from the external ear canal of an inpatient in a Japanese hospital. Microbiol. Immunol. 53: 41-44.

54. Singleton VL, Orthofer R, Lamuela-Raventós RM. 1999. Analysis of total phenols and other oxidation substrates and antioxidants by means of folin-ciocalteu reagent. Methods Enzymol. 299: 152-178.

55. Stojanoski N. 1999. Development of health culture in Veles and its region from the past to the end of the 20th century. Veles: Society Sci. Art. 13.

56. Supandi Y, Merdekawati F. 2018. In silico study of pyrazolylaminoquinazoline toxicity by lazar, protox, and admet predictor. J. App. Pharmaceut. Sci. 8: 119-129.

57. Tappy L, Lê KA, Universitaire VL. 2010. Metabolic effects of sweetened beverages: Pathophysiology and mechanistic insights. Heart Diseas. 4, 5.

58. Tolosa J, Barba FJ, Pallarés N, Ferrer E. 2020. Mycotoxin identification and in silico toxicity assessment prediction in Atlantic Salmon. Marine Drugs. 18: 629.

59. Trott O. Olson AJ. 2010. AutoDock Vina: improving the speed and accuracy of docking with a new scoring function, efficient optimization, and multithreading. J. Comput. Chem. 31: 455-461.

60. Tsuchido T, Hiraoka T, Takano M, Shibasaki I. 1985. Involvement of autolysin in cellular lysis of Bacillus subtilis induced by short- and medium-chain fatty acids. J. Bacteriol. 162: 42-46.

61. van Vuuren S, Viljoen A. 2011. Plant-based antimicrobial studies-methods and approaches to study the interaction between natural products. Planta Medica. 77: 1168-1182.

62. Wangchuk P, Namgay K, Gayleg K, Dorji Y. 2016. Medicinal plants of Dagala region in Bhutan: their diversity, distribution, uses and economic potential. J. Ethnobiol. Ethnomed. 12: 28.

63. Wojciechowska P, Tichoniuk M, Gwiazdowska D, Maciejewski H, Nowicki M. 2018. Antimicrobial activity of organic-inorganic hybrid films based on gelatin and organomodified silicones. Adv. Polym. Technol. 37: 2958-2970.

64. World Health Organization 2016. World malaria report 2015. World Health Organization.

65. Wyrobnik DH, Wyrobnik IH, 2018. Vitamerica Ug (haftungsbeschrankt), Agent for use in the case of fructose intolerance. U.S. Patent Application 15/871,597. 
66. Yi T, Li SM, Fan JY, Fan LL, Zhang ZF, Luo P, Zhang XJ, Wang JG, Zhu L, Zhao ZZ, Chen HB, 2014. Comparative analysis of EPA and DHA in fish oil nutritional capsules by GC-MS. Lipids in Health and Dis. 13: $1-6$.

67. Yu HH, Kim KJ, Cha JD, Kim HK, Lee YE, Choi NY, You YO. 2005. Antimicrobial activity of berberine alone and in combination with ampicillin or oxacillin against methicillin-resistant Staphylococcus aureus. J. Med. Food. 8: 454-461.

68. Zhishen J, Mengcheng T, Jianming W. 1999. The determination of flavonoid contents in mulberry and their scavenging effects on superoxide radicals. Food chem. 64: 555-559.

\section{Figures}

A

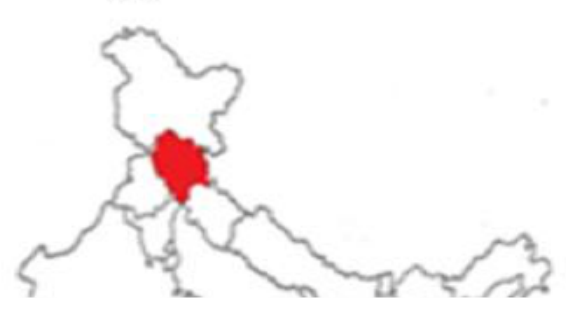

B

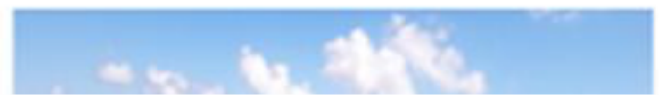

\section{Figure 1}


Geographical location of B. macrophylla. Map of India showing Himachal Pradesh as red shade as North Indian state (A), Map of Himachal Pradesh Showing Shimla district in blue shade (B), Natural View of Chanshal Valley, from where B. macrophylla was collected (C), B. macrophylla in natural habitat (D), and Rhizome of $B$. macrophyllaused in the current study (E).

\begin{tabular}{|c|c|c|c|c|c|c|c|c|c|c|c|c|c|}
\hline & 1 & 2 & 3 & 4 & 5 & 6 & 7 & 8 & 9 & 10 & 11 & 12 \\
\hline & & \multicolumn{12}{|c|}{ Minimum inhibitory concentration (MIC) in $\mu \mathrm{g} / \mathrm{ml}$ ) } \\
\hline & & 500 & 250 & 125 & 62.5 & 31.25 & 15.62 & 7.81 & 3.9 & 1.95 & 0.97 & 0.49 & 0.24 \\
\hline \multicolumn{14}{|c|}{ MIC Extract } \\
\hline \multicolumn{14}{|c|}{ MIC Antibiotics } \\
\hline \multirow{3}{*}{$\begin{array}{l}2 \mathrm{MIC} \\
\text { Extract }\end{array}$} & 2MIC+Antibiotics & & & & & & & & & & & & \\
\hline & MIC+Antibiotics & & & & & & & & & & & & \\
\hline & 1/2 MIC+Antibiotics & & & & & & & & & & & & \\
\hline \multirow{3}{*}{$\begin{array}{l}\text { MIC } \\
\text { Extract }\end{array}$} & 2MIC+Antibiotics & & & & & & & & & & & & \\
\hline & MIC+ Antibiotics & & & & & & & & & & & & \\
\hline & 1/2 MIC+Antibiotics & & & & & & & & & & & & \\
\hline \multirow[t]{3}{*}{$1 / 2 \mathrm{MIC}$} & 2MIC+Antibiotics & & & & & & & & & & & & \\
\hline & MIC+ Antibiotics & & & & & & & & & & & & \\
\hline & 1/2 MIC+Antibiotics & & & & & & & & & & & & \\
\hline
\end{tabular}

Figure 2

Schematic diagram to measure the synergistic activity between methanolic extract of rhizome of $B$. macrophylla and antibiotics (fluconazole or amphotericin B) using different dilutions. Assay was done using 96 wells micro titer plates. Purple color indicates dead cells, whereas pink color represents viable cells. 
A

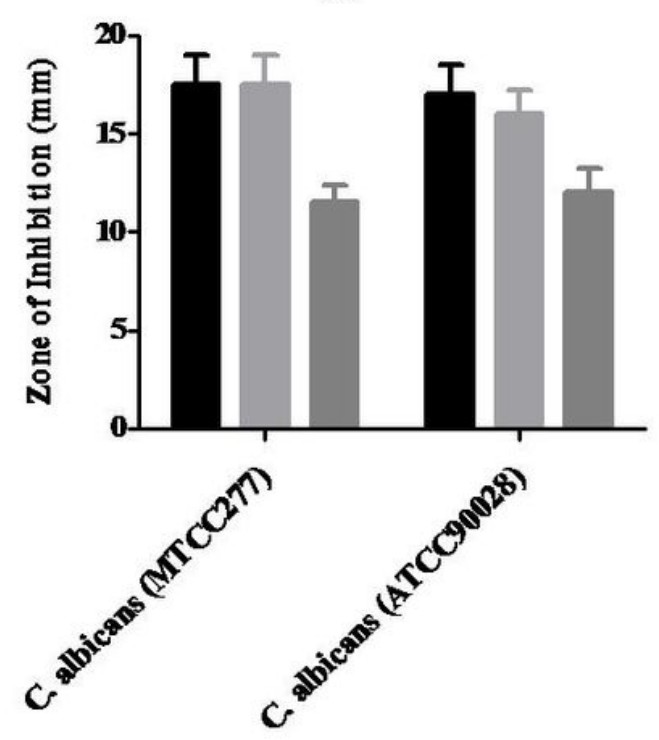

B

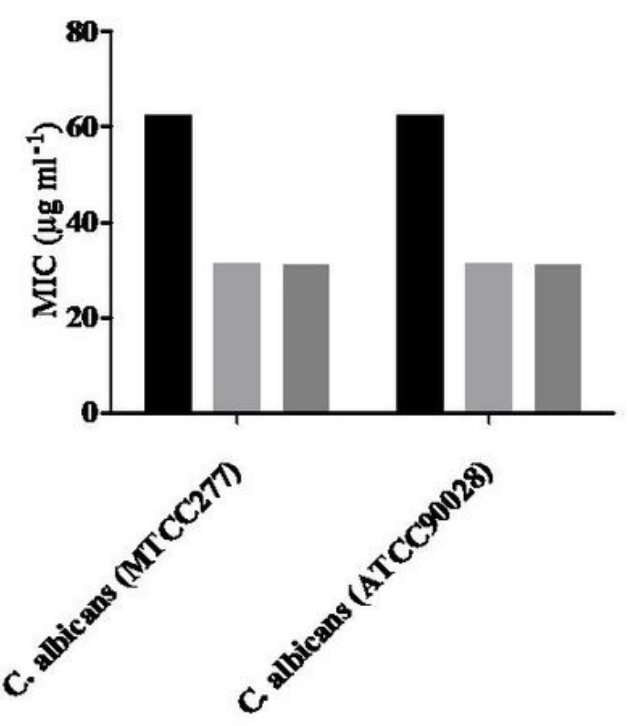

Methanolic Extract

Fluoonazole

Amphotericin B

Figure 3

Qualitative and Quantitative methods to measure antifungal activity of methanolic extract of B. macrophylla. Methanolic extracts were subjected to: (A) antifungal activity by agar well diffusion method and (B) antifungal activity measured by broth dilution methods against S. cerevisiae (H1086), C. albicans (MTCC277 and ATCC90028). Fluconazole and amphotericin B were used as positive controls in both the assays.

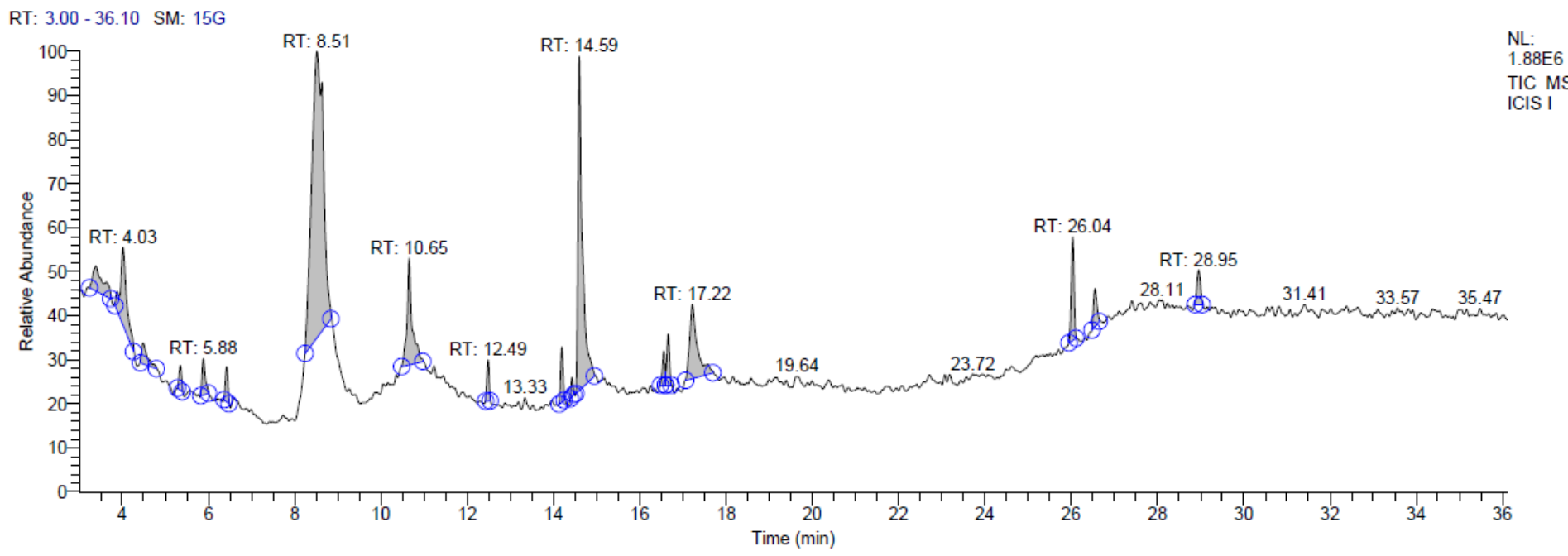

Figure 4

GC-MS fingerprint of methanolic extract of B. macrophylla showing Time (min) at X-axis (RT) and relative abundance at $Y$-axis. 
A
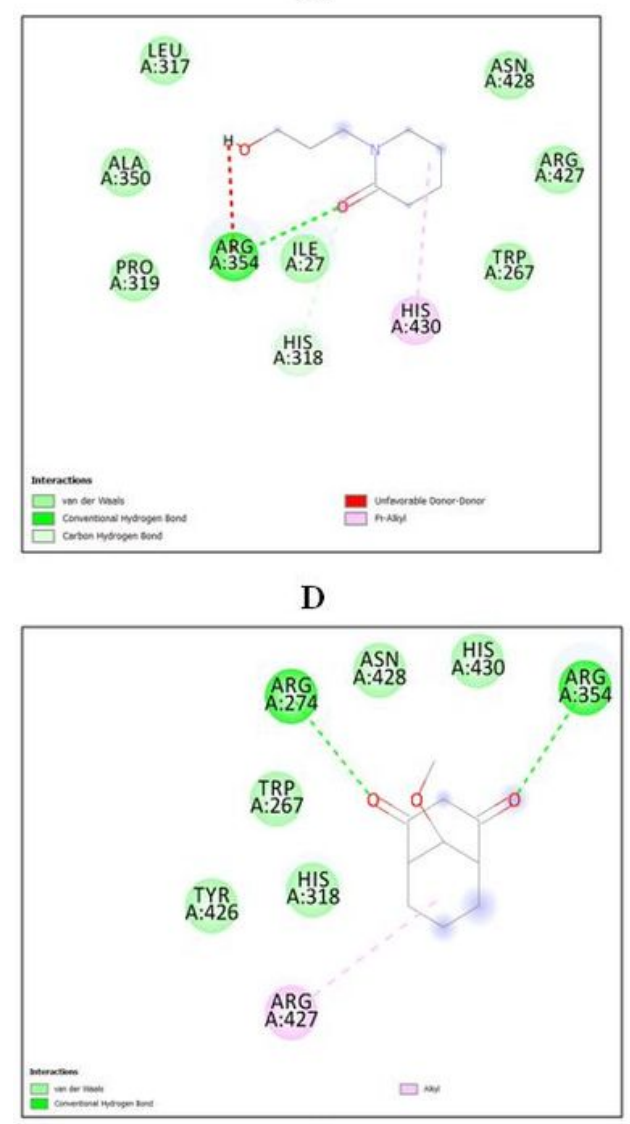

G

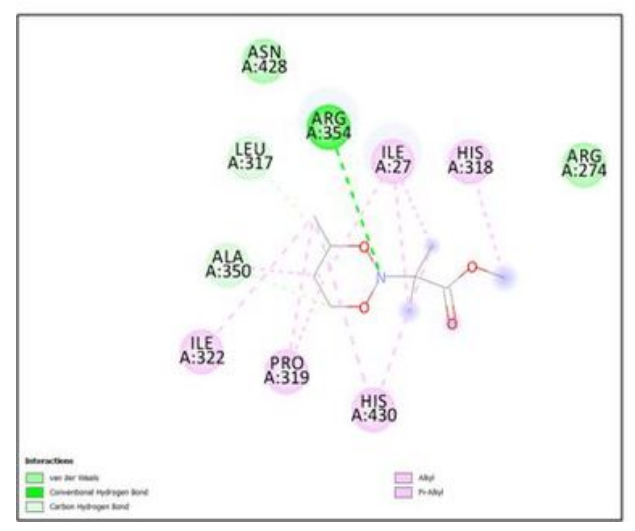

B

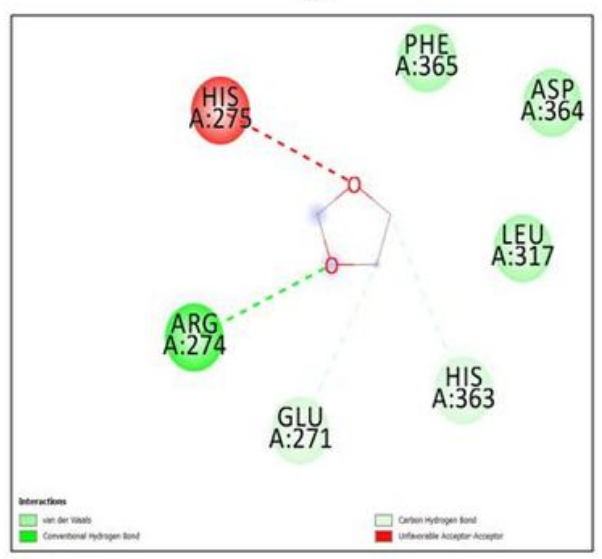

E

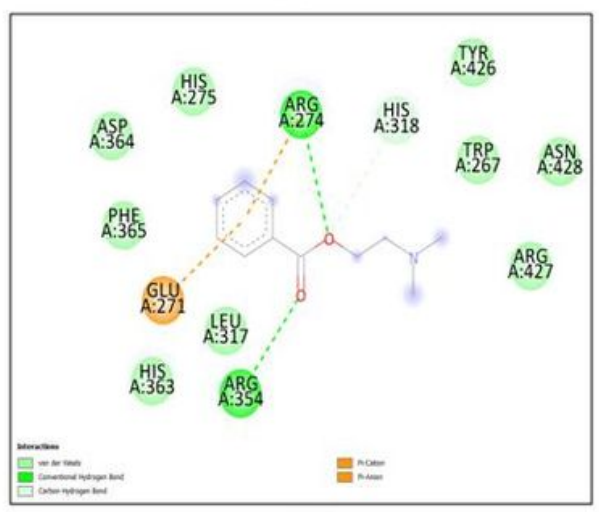

H

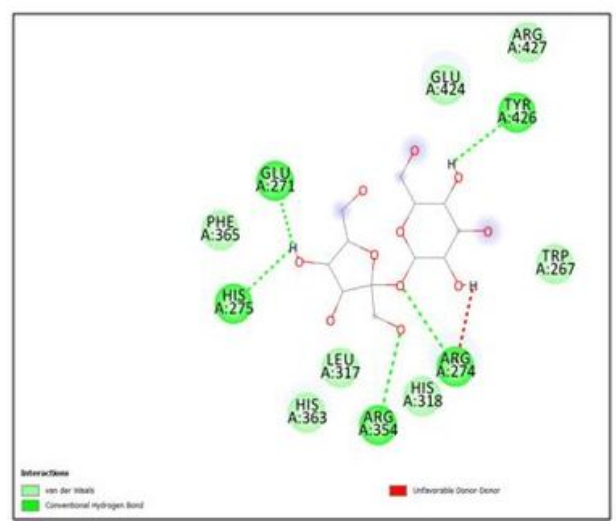

C
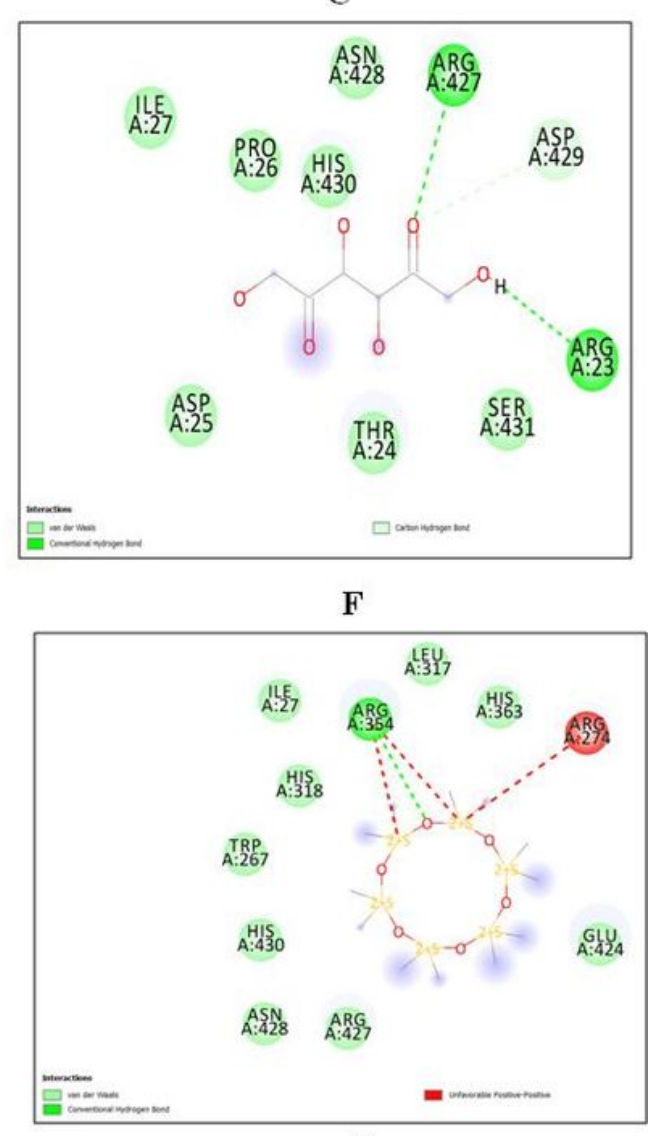

I

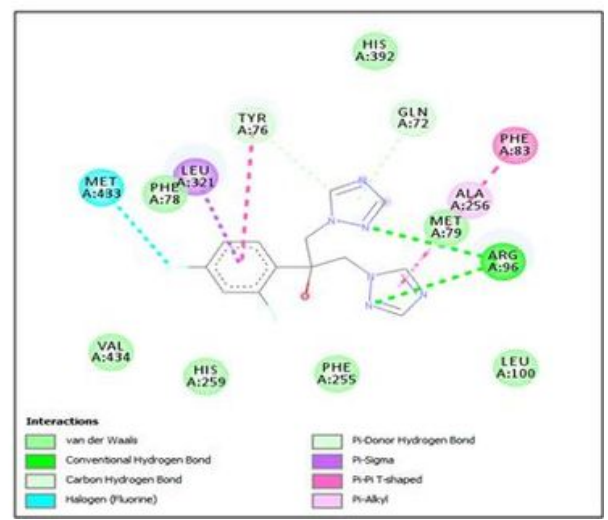

Figure 5

2D interactions of $\boldsymbol{B}$. macrophylla with fungal target protein (1EA1): (A) 1-(3-Hydroxypropyl)-2-piperidinone, (B) 1,3-Dioxolane, (C) 5-Keto-D-fructose, (D) 9,9-Dimethoxybicyclo [ 3.3.1] nona-2,4-dione, (E) Benzoic acid, 2(dimethylamino) ethyl ester,(F) Benzoic acid, 2-(dimethylamino) ethyl ester, (G) N-(1-Methoxycarbonyl-1methylethyl)-4-methyl-2-aza-1,3-dioxane, $(\mathrm{H})$ Sucrose and (I) Fluconazole 
3D interactions of $B$. macrophylla with fungal target protein (1EA1): (A) 1-(3-Hydroxypropyl)-2-piperidinone, (B) 1,3-Dioxolane, (C) 5-Keto-D-fructose,(D) 9,9-Dimethoxybicyclo [3.3.1] nona-2,4-dione, (E) Benzoic acid, 2(dimethylamino) ethyl ester,(F) Benzoic acid, 2-(dimethylamino) ethyl ester, (G) N-(1-Methoxycarbonyl-1methylethyl)-4-methyl-2-aza-1,3-dioxane, (H) Sucrose and (I) Fluconazole.

\section{Supplementary Files}

This is a list of supplementary files associated with this preprint. Click to download.

- floatimage1.jpeg 